\title{
Status and distribution of White-winged Black Tit Parus nuchalis in Kachchh, Gujarat, India
}

\author{
S. A. HUSSAIN, S. ASAD AKHTAR and J. K. TIWARI
}

\begin{abstract}
Summary
The White-winged Black Tit Parus nuchalis is an endemic Indian species threatened by the destruction of its Acacia scrub forest habitat. Historical and recent unpublished records are here combined to provide a new assessment of its disjunct range. Only three records exist from its southern area of distribution; against this, there were 27 sightings of up to four individuals between 1976 and 1991 at 14 localities in Kachch. The species urgently needs measures to preserve its habitat, and particularly its nest trees.
\end{abstract}

\section{Introduction}

The White-winged Black Tit Parus nuchalis is a resident Indian species with a very restricted and disjunct range in the west and the south of the country (Ali and Ripley 1973; see Figure 1). The available information indicates that the species has declined drastically, primarily owing to habitat destruction. It has been included in the ICBP checklist of threatened birds (Collar and Andrew 1988), and needs the immediate attention of wildlife managers and conservationists. In this paper we report on the species in part of its western area of distribution, which appears to be the more important for its conservation.

The White-winged Black Tit (Plate 1) was first obtained and described by Jerdon in 1844 from the Eastern Ghats west of Nellore. Another specimen was collected at Bangalore (Baker 1922), while one more specimen, now apparently lost, was collected at Satyamangala (about $600 \mathrm{~m}$ ) in the Biligirirangan hills in south-east Mysore district. These are the only three known records of this species from peninsular India (Ali and Ripley 1973), and Ali (1945) concluded that it was very rare there. A specimen in the British Museum from the Gadow collection is labelled Bhutan, which Baker (1922) felt was mistaken.

The distribution of the White-winged Black Tit in north-western India comprises Kachchh, northern Gujarat (Deesa, Palanpur, Mehsana), central and south-central Rajasthan (Pali, Jodhpur, Nasirabad, Ajmer, Kishangarh, Jhalawar, and Sambhar lake). Adam (1873) and Butler (1875) reported it to be quite common in this western range. Adam obtained 12 specimens in a patch of jungle near Marot (Rajasthan), where it seemed to be so common that every collecting trip yielded one or more specimens. He also reported it from a range of hills towards the marble quarries of Makrana.

The present distribution of the White-winged Black Tit in Kachchh is mapped on the basis of 27 sightings of the bird made by seven birdwatchers and naturalists during 1976 to 1991 (Figure 2). This includes our own field observations 


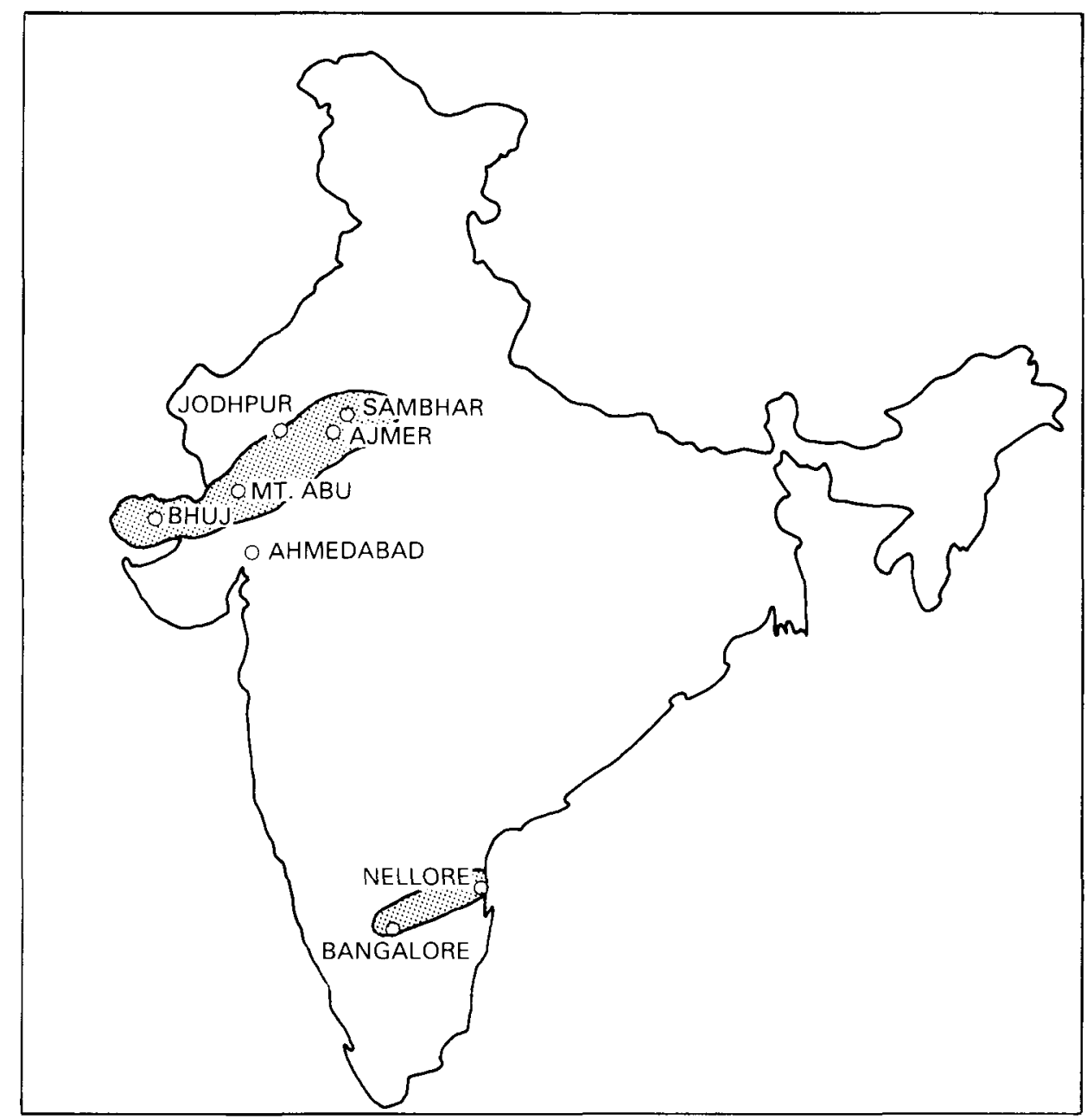

Figure 1. Distribution of White-winged Black Tit Parus nuchalis in India.

made for the Bombay Natural History Society (BNHS) between January 1990 and March 1991.

\section{Materials and methods}

Thorny scrub forest dominated by Acacia catechu and Acacia nilotica is the ideal and preferred habitat of the White-winged Black Tit (Plate 2). Besides this habitat, we also surveyed the other habitats in the areas, i.e. grassland and Prosopis-dominated scrub.

A compilation of all sightings of the White-winged Black Tit in Kachchh (Tables 1 and 2) is made here based on (a) literature survey, (b) bird surveys, (c) random and intensive mist-netting in representative tit habitats, (d) census by line transect method (Emlen 1971), (e) nest surveys, and (f) information gathered from birdwatchers and other naturalists in the area. 


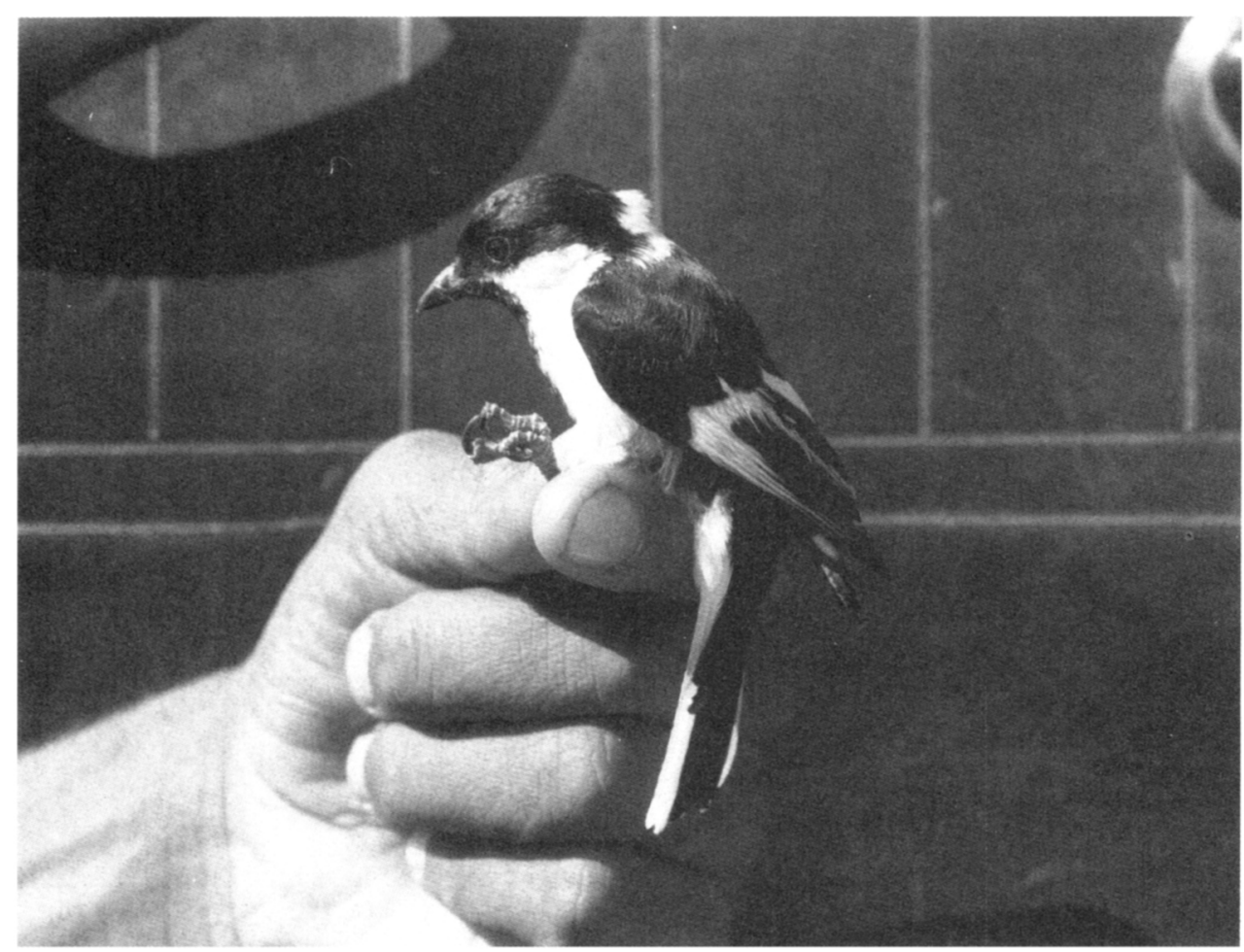

Plate 1. White-winged Black Tit.

\section{Results}

The 27 sightings of the White-winged Black Tit recorded from 1976 to 1991 were mainly confined to three of the nine administrative "talukas" (blocks) of Kachchh district, namely Bhuj, Nakhtrana and Lakhpat (Figure 2). Two adult birds were ringed, one in Jathaveera "rakhal" (protected forest) (Taluka Nakhtrana) and one in Matanomadh rakhal (Taluka Lakhpat). The Jathaveera rakhal registered the maximum number of sightings. The second stronghold is in a privately owned scrub forest in Fulay village (Taluka Nakhtrana). The sightings have been typically of one or two birds except for a single gathering of four recorded at Fulay rakhal on 5 January 1990. We maintained a nest search from May to August 1990 in the scrub forests where the tit has been recorded, but found none. A few nest-boxes were also put up in Jathaveera rakhal, but they were destroyed by vandals. The bird is known to nest in natural hollows mostly made by woodpeckers in old tree-trunks. Lester (1904) reported its occurrence and breeding on the borders of the Rann around Koonria and Doria Soomrasir (Figure 2). The literature survey revealed $x 8$ records of the bird scattered over Rajasthan, Kachchh, Gujarat, Karnataka and Andhra Pradesh between 1844 and 1943 (Tables 2, 3). 


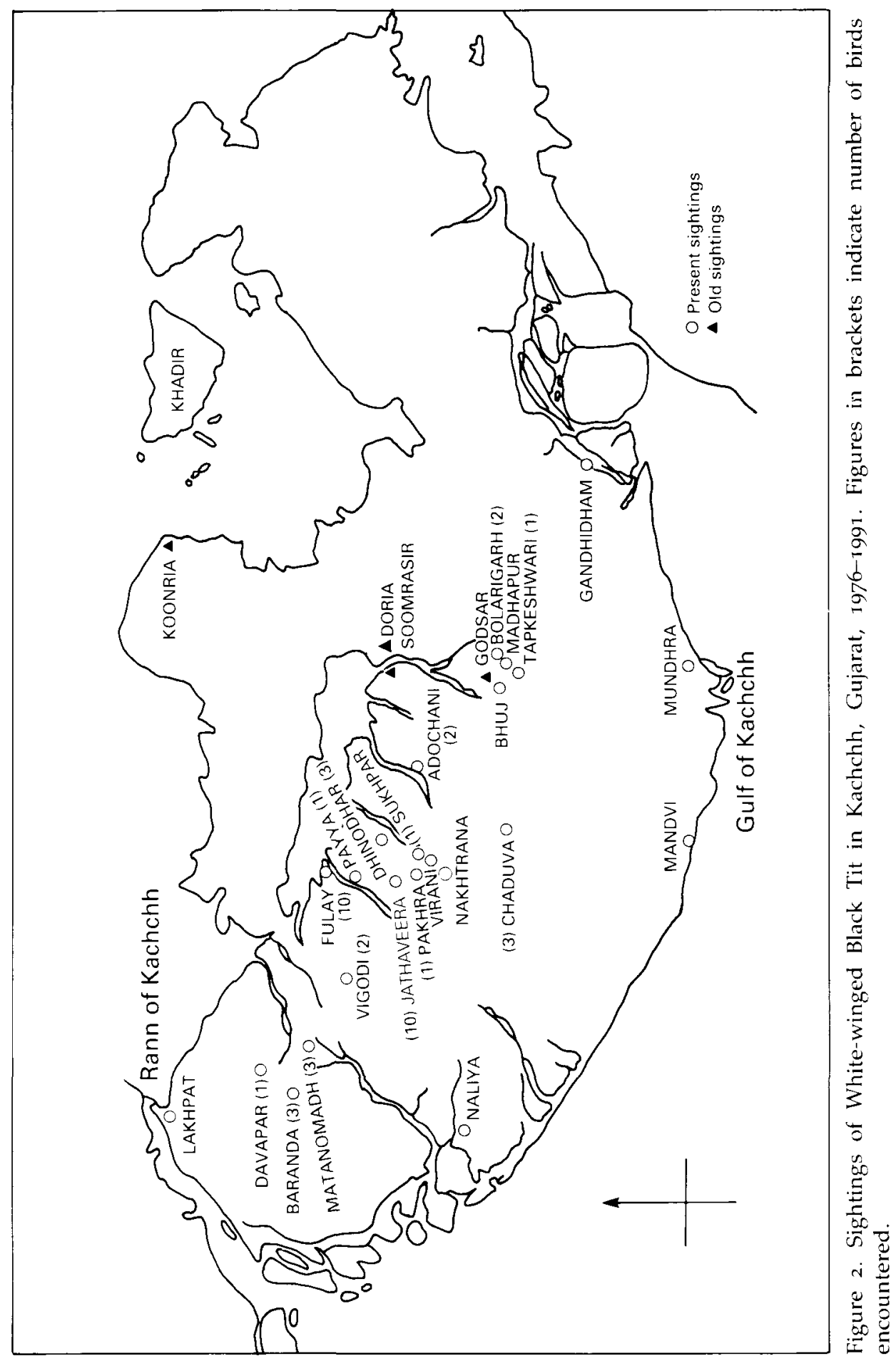




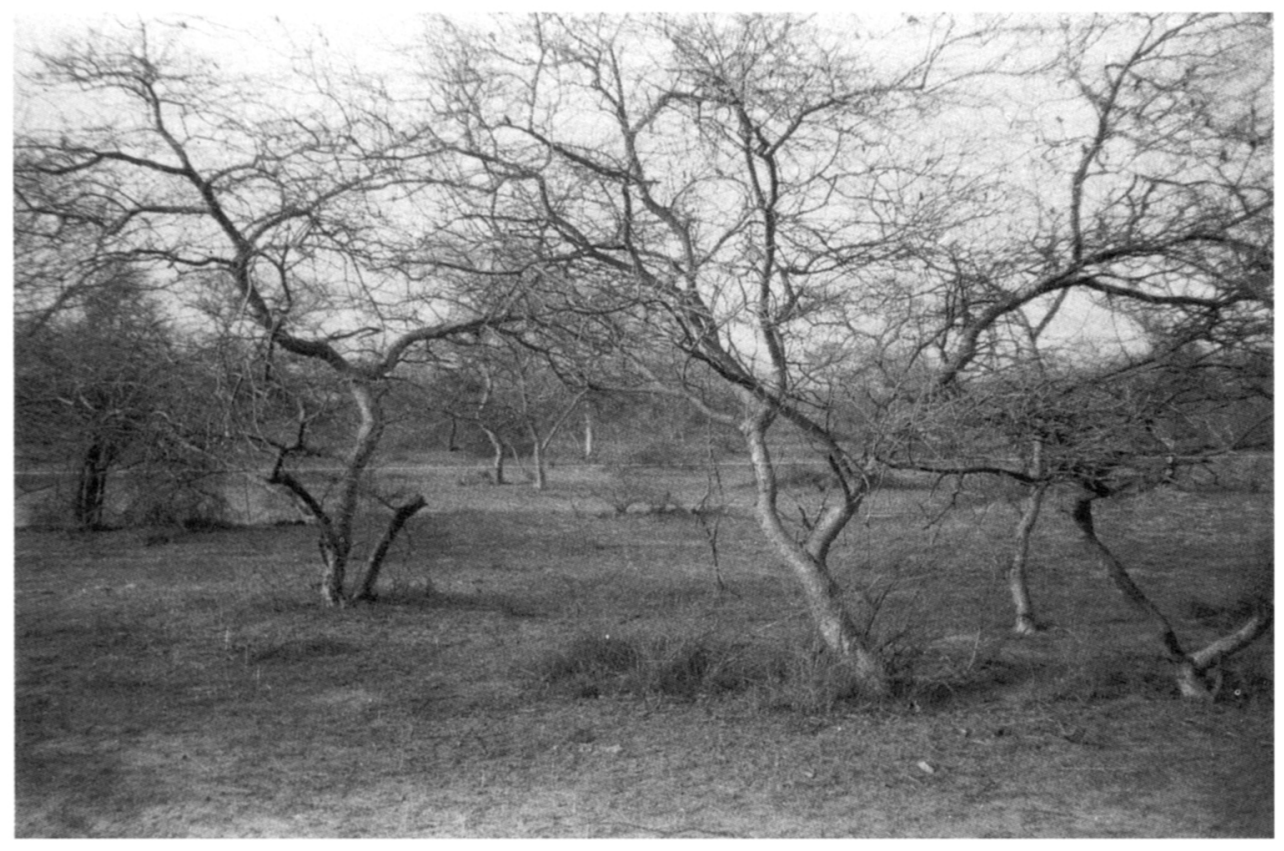

Plate 2. Typical habitat of the White-winged Black Tit at Jathaveera/Fulay, Kachchh.

\section{Discussion}

Our observations support reports (Ali and Ripley 1973) that the White-winged Black Tit is found in parties of $2-4$ birds. We found it to be extremely shy, disclosing its presence only by musical whistling notes, tee-whi-whi or tee-whiwhi-whi (see pit-pit-pit-pit). The tit was mainly observed in Acacia catechu forest, flitting from tree to tree and adopting various acrobatic positions in its restless search for insects and spiders.

Butler (1875) reported it to be rare on and around Mount $\mathrm{Abu}$ and in northern Gujarat. However, Hume (1875), commenting on Butler's notes, considered it to be not uncommon in its western range. He reported sightings from all round the Sambhur lake, Kishengarh and Ajmer, from around Pali near Jodhpur and also from near Soeegam on the Rann of Kachchh and at several other localities in Kachchh. He also noted that the western form of the species could prove distinct, as it did not agree perfectly with Jerdon's description, which was based on a southern specimen. He further highlighted the difference between the habitats obtaining in its southern and western ranges and the absence of the species in any intermediate localities. He felt that this distribution was worth investigation.

In fact, the unusual distribution of the White-winged Black Tit can very simply be explained by the absence of a continuous tract of scrub forest between the two distributional ranges. The only three records of this species from southern India suggests a relict population which was presumably isolated as the forest cover between the regions slowly disappeared. It is of considerable importance to establish whether this population still exists. In the western area of its distribution, dry forest cover is rapidly diminishing, so that the future of this species 
Table 1. Recent sight records of White-winged Black Tit

\begin{tabular}{|c|c|c|c|c|}
\hline S No. & $\begin{array}{l}\text { Chronology of } \\
\text { sightings }\end{array}$ & Locality & Nos. & Source/remark \\
\hline 1 & 01.08 .76 & Dhinodhar & 2 & S. N. Varu \\
\hline 2 & 14.07 .84 & Dayapar & 1 & S. N. Varu \\
\hline 3 & 14.09 .86 & Tapkeshwari & 1 & N. N. Bapat \\
\hline 4 & 18.09 .86 & Adochani dam & 1 & N. N. Bapat \\
\hline 5 & 22.11 .86 & Chaduva & 1 & S. N. Varu \\
\hline 6 & 22.02 .87 & Vigodi & 2 & S. N. Varu \\
\hline 7 & 29.07 .87 & Adochani dam & 1 & N. N. Bapat \\
\hline 8 & 29.02 .88 & Chaduva & 1 & N. N. Bapat \\
\hline 9 & 24.06 .89 & Chaduva & 1 & N. N. Bapat \\
\hline 10 & 04.09 .89 & Dhinodhar & 1 & S. N. Varu \\
\hline 11 & 25.09 .89 & Barenda & 3 & Ravi Sankaran \\
\hline 12 & 05.01 .90 & Fulay & 4 & * \\
\hline 13 & 20.02 .90 & Jathaveera & 2 & * \\
\hline 14 & 10.03 .90 & Bolarigarh & 2 & N. N. Bapat \\
\hline 15 & 17.03 .90 & Fulay & 2 & $*$ \\
\hline 16 & 23.03 .90 & Fulay & 1 & * \\
\hline 17 & 26.03 .90 & Jathaveera & 3 & * \\
\hline 18 & 27.04 .90 & Sukhpar virani & I & * \\
\hline 19 & 24.07 .90 & Jathaveera & 2 & * \\
\hline 20 & 22.08 .90 & Jathaveera & 1 & * \\
\hline 21 & 10.09 .90 & Pakhda & 1 & * \\
\hline 22 & 07.11 .90 & Payya & 1 & * \\
\hline 23 & 03.01 .91 & Jathaveera & 1 & * Census \\
\hline 24 & 03.01 .91 & Jathaveera & 1 & * Ringed \\
\hline 25 & 07.01 .91 & Matanomadh & 1 & * Ringed \\
\hline 26 & 07.01 .91 & Matanomadh & 2 & * \\
\hline 27 & 11.01 .91 & Fulay & 3 & * \\
\hline
\end{tabular}

* Sightings by BNHS team.

Biometrics of specimens ringed

$\mathrm{S}$ no. 24 : ring no. A-233761, wing $-66 \mathrm{~mm}$, bill $-12.0 \mathrm{~mm}$, tarsus $-17 \mathrm{~mm}$, tail $-\mathrm{xxx}$, weight $-13.0 \mathrm{~g}$.

S no. 25 : ring no. A-233767, wing $-67 \mathrm{~mm}$, bill $-12.5 \mathrm{~mm}$, tarsus $-17 \mathrm{~mm}$, tail $-55 \mathrm{~mm}$, weight $-14.5 \mathrm{~g}$.

appears to be very bleak. As elsewhere there has been a continuous and rapid increase in the human and livestock population in Kachchh. The livestock is often fed with branches of trees, particularly Acacia. Owing to the resultant lopping and felling, the scrub tree density is decreasing and forest is becoming sparse everywhere. Loss of nesting habitat in this region certainly appears to be the main cause for the decline in numbers of this natural hole-nesting species. The Godsar rakhal, for example, has been entirely lost owing to agricultural encroachment of the people in and around the town of Sukhpar. The preservation of tracts of forest and of suitable nest trees within them must be the highest priority in any modern efforts to save the White-winged Black Tit. 
Table 2. Earlier sight records of White winged Black Tit

\begin{tabular}{|c|c|c|c|c|}
\hline Sl. No. & Date & Locality & Nos. & Source/remark \\
\hline 1 & 1844 & $\begin{array}{l}\text { Eastern Ghats, west of Nellore, } \\
\text { Andhra Pradesh }\end{array}$ & 1 & $\begin{array}{l}\text { T. C. Jerdon } \\
\text { A specimen collected for first } \\
\text { description of the species }\end{array}$ \\
\hline 2 & 1863 & Bangalore, Karnataka & 1 & $\begin{array}{l}\text { Dr Stewart } \\
\text { Specimen collected }\end{array}$ \\
\hline 3 & 1863 & $\begin{array}{l}\text { Satyamangalam, } \\
\text { Biligirirangan hills, } \\
\text { Karnataka }\end{array}$ & 1 & Specimen is apparently lost \\
\hline 4 & 1873 & Marot, Rajasthan & 14 & $\begin{array}{l}\text { R. M. Adams } \\
\text { Specimens collected }\end{array}$ \\
\hline 5 & 1875 & Sambhur Lake, Rajasthan & - & A. O. Hume, observation \\
\hline 6 & 1875 & Kishengarh, Rajasthan & - & A. O. Hume, observation \\
\hline 7 & 1875 & Ajmer, Rajasthan & - & A. O. Hume, observation \\
\hline 8 & 1875 & Pali, Rajasthan & - & A. O. Hume, observation \\
\hline 9 & 1875 & Soeegam, Rann of Kachchh & - & A. O. Hume, observation \\
\hline 10 & 1875 & Deesa, Gujarat & - & Capt. E. A. Butler \\
\hline 11 & 23.12 .1895 & Koonria (Kutch) & 2 & C. D. Lester, observation \\
\hline 12 & July 1896 & Godsar (Kutch) & I & C. D. Lester, specimen \\
\hline 13 & July 1931 & Taranga hill (Mehsana) & - & R. M. Simmons, observation \\
\hline 14 & Feb. 1932 & Taranga hill (Mehsana) & - & R. M. Simmons, observation \\
\hline 15 & 1937 & Bhujia Fort (Bhuj) & 1 & H. Abdulali \\
\hline 16 & 08.08 .43 & Bhujia Fort (Bhuj) & 1 & S. Ali, Bird ringed \\
\hline 17 & 10.08 .43 & Tapkeshwari (Bhuj) & 2 & S. Ali, observation \\
\hline 18 & 04.04 .44 & Bhujia Fort (Bhuj) & 1 & S. Ali ${ }^{\text {a }}$ \\
\hline
\end{tabular}

a Bird ringed on 08.08 .43 at roost sighted on 04.04 .44 at the same roost.

\section{Acknowledgements}

We are grateful to M. K. S. Himmatsinhji, S. N. Varu, N. N. Bapat, and Trilochan Chhaya of the Pelican Nature Club (Bhuj, Kachchh), and Ravi Sankaran of the Bombay Natural History Society for providing their valuable field data for this paper. Fieldwork for ringing birds was carried out as BNHS Bird Migration Project funded by a PL-480 grant No. 14-16-0009-87-02 by U.S. Fish and Wildlife Service and sponsored by the Ministry of Environment, Government of India.

Table 3. White-winged Black Tit specimens in the Bombay Natural History Society collection

\begin{tabular}{llll}
\hline Date & Place of collection & Sex & Collected by \\
\hline July 1896 & Kachchh & $\mathrm{M}$ & C. D. Lester \\
$\mathbf{1 8 . 0 2 . 3 9}$ & Bhuj & $\mathrm{F}$ & Sir G. F. Archer \\
$\mathbf{2 7 . 0 2 . 3 9}$ & Bhuj & $\mathrm{M}$ & Sir G. F. Archer \\
$\mathbf{1 2 . 0 8 . 4 3}$ & Godsar, Bhuj & $\mathrm{M}$ & Salim Ali \\
$\mathbf{1 2 . 0 8 . 4 3}$ & Godsar, Bhuj & $\mathrm{F}$ & Salim Ali \\
$\mathbf{1 8 . 0 8 . 4 3}$ & Chaduva, Bhuj & $\mathrm{M}$ & Salim Ali \\
$\mathbf{2 0 . 0 8 . 4 3}$ & Chaduva, Bhuj & $\mathrm{F}$ & Salim Ali \\
$\mathbf{2 0 . 0 8 . 4 3}$ & Chaduva, Bhuj & $\mathrm{M}$ & Salim Ali \\
26.09 .43 & Kachchh & $\mathrm{M}$ & Salim Ali \\
$\mathbf{2 7 . 0 9 . 4 3}$ & Kachchh & $\mathrm{M}$ & Salim Ali \\
17.03 .44 & Matanomadh, Kachchh & $\mathrm{F}$ & Salim Ali \\
11.01 .46 & Deesa, Palanpur & $\mathrm{M}$ & Salim Ali \\
18.01 .46 & Gangasagar & - & Salim Ali \\
\hline
\end{tabular}

\footnotetext{
a Specimens donated to Zoological Survey of India, Calcutta.
} 


\section{References}

Abdulali, H. (1949) Some peculiarities of avifaunal distribution in peninsular India. Proc. Natl. Inst. Sci. India 15: 309-314.

Adam, R. M. (1873) Notes on the birds of the Sambhar Lake and its vicinity. Stray Feathers 1: $361-404$.

Ali, S. (1945) The birds of Kutch. Bombay: Oxford University Press.

Ali, S. and Ripley, S. D. (1973) The handbook of the birds of India and Pakistan, 9. Delhi: Oxford University Press.

Baker, E. C. S. (1922) Fauna of British India, (Birds), 1. London: Taylor and Francis.

Butler, E. A. (1875) Notes on the avifauna of Mount Aboo and northern Gujarat. Stray Feathers 3: 437-500.

Collar, N. J. and Andrew, P. (1988) Birds to watch: the ICBP world checklist of threatened birds. Cambridge, U.K.: International Council for Bird Preservation (Techn. Publ. 8).

Emlen, J. T. (1971) Population densities of birds derived from transect counts. Auk 88: 323-342.

Gaston, A. J. (1984) Is habitat destruction in India and Pakistan beginning to affect the status of endemic passerine birds? J. Bombay Nat. Hist. Soc. 81: 636-641.

Hume, A. O. (1875) [Editorial note.] Stray Feathers 3: 492.

Lester, C. D. (1904) The birds of Kutch. Bhuj, Kutch: Kutch Darbar.

\section{S. A. HUSSAIN}

Bombay Natural History Society, Hornbill House, Shaheed Bhagat Singh Road, Bombay 400 023, India.

\section{S. ASAD AKHTAR}

Bombay Natural History Society, Hornbill House, Shaheed Bhagat Singh Road, Bombay 400 023, India.

\section{J. K. TIWARI}

Bombay Natural History Society, Hornbill House, Shaheed Bhagat Singh Road, Bombay 400 023, India. 